By JOSE MEYER

\title{
Government Publications
}

\section{French Official Publications in the Second World War}

Miss Meyer of the Descriptive Cataloging Division of the Library of Congress, has been the representative of the Library of Congress in France until her recent return to this country.

When war began in September 1939 there was an initial period of complete disruption of all normal activity, both public and private. This was due to two major reasons: the contingencies of the general mobilization to which everything else became subordinate and the generally held belief that military operations would begin with an all-out air attack against Paris and the larger cities of France. What appeared to the uninitiated observer as a state of utter confusion proved to be the execution of a minutely established plan, details of which were laid down in the form of a law as early as July II, 1938. There were several editions of this document including the original issue in the Journal officiel, also separately printed. In September 1939 it was widely distributed as:

Présidence du Conseil. Organisation générale de la Nation pour le Temps de Guerre. Documents officiels au Jour au $I^{\text {er }}$ juin 1939. Paris, Berger-Levrault, 1939.

After several weeks of suspended activity in all matters but the business of war, the government departments, learned institutions, and educational establish- ments resumed their regular routine with but few changes.

The Journal officiel and various government publications continued on the whole as previously, although sometimes with more delay than usual.

One immediate result of the state of war was the suspension of the sale and distribution of all maps and publications of the Service géographique de l'Armée and of the Service hydrographique de la Marine. On the other hand, after a few months the Geographical Service began what was to be a pictorial record of the war for popular distribution but which never got beyond the first number. ${ }^{1}$

The international exchange of learned societies and government publications was interrupted not so much on account of the war as for lack of funds. However, in December 1939 a small sum was made available by the Ministry of Education which enabled the Exchange Service to ship publications accumulated since May I 939 to their various destinations.

In this connection it may be stated that work on the Inventory of French Official Publications ${ }^{2}$ which was begun in 1937 , has continued without interruption under the auspices of the Commission des Publi-

\footnotetext{
1 Service geographique de l'Armee. Memorial de la Guerre. No. I, janvier 1940. Paris, Section photographique et cinematographique de l'Armee photographique et cinematographique de Prmee 1940 . 2 istere de l'Education nationale. Inventaire ${ }^{2}$ Ministere de l'Education nationale. Inventaire
general des Publications officielles. Premiere serie: Institutions generales de l'Etat. t. I ${ }^{2}$ : Publications administratives et techniques. 1937-38. Paris, Librairie Berger-Levrault, 1940.
} 
cations Administratives and the Bibliothèque Nationale. The former was established by decree of August 6, 1937 . Funds for the undertaking were made available by Parliament in I938. In December 1940, six months after the German occupation, the first volume was in press. Examination of the page proof of the opening section shows that the approach is both historical and legal. The introduction includes the history of the project, the text of the legislative acts bearing on French government publications, an outline of the plan of the inventory and definitions of what constitutes official and semiofficial publications. This is followed by the list of parliamentary publications, with a lucid expose of parliamentary procedure as regards official acts. The administrative and technical publications of the executive departments of the central government are similarly treated. Part 2 will cover publications of learned bodies, also maps and charts; Part 3, departmental and municipal publications; Part 4, publications of the colonies and protectorates.

\section{New Publications}

In the early stages of the war a number of new publications were undertaken. Outstanding among these is the Bulletin analytique ${ }^{3}$ issued by the Centre National de la Recherche Scientifique, which embodies abstracts from French and foreign scientific publications. Plans for this enterprise, which was of vital importance for national defense, were made soon after the outbreak of war, coincident with the reorganization of the Centre de la $\mathrm{Re}$ cherche Scientifique (decree of October

3 Ministere de l'Education nationale. Centre de la Recherche scientifique. Bulletin analytique. Vol. I, No. I/6-, janvier-mars I940-Paris, Service de

DECEMBER, 1941
19, I939). The first number marked I 6 and dated January-March I940 included digests for the period September I939 to March I940. Although the bulletin was originally planned as a semimonthly, the following issue was again a double number, $7 / 8$, dated April I940. Number 9 appeared on May 15. The bulletin was temporarily suspended at the time of the German advance, but Pierre Auger, the editor, was back at his post in Paris in October 1940, hopeful of being able to resume work on the publication, although with obvious limitations.

The Ministère de l'Armement was created by decree of September 20, 1939. It was headed by Raoul Dautry, formerly director of the Chemin de Fer de l'Etat. All of its publications, chiefly in mimeograph form, were of a confidential nature with the exception of a small series of which only two numbers appeared before the occupation, others being in press at the time :

Ministère de l'Armement. Guide $d u$ Fournisseur du Ministère de l'Armement. octobre 1939.

- Votre Main-d'suvre. Guide No. 2 du fournisseur. [1940?]

The mass shifting of populations from Alsace-Lorraine in the immediate zone of war operations to the central departments was responsible for the bilingual weekly De l'Est à l'Ouest. ${ }^{4}$ This was published by the prefect of Charente-Inférieure in French and German as a sort of first aid and liaison bulletin for bewildered Alsace and Lorraine families uprooted from their homes without warning and frequently torn apart in the confusion.

4 Préfecture de la Charente-Inférieure. Secretariat general De l'Est a l'Ouest. Bulletin de Renseignements pour les Evacues. Auskunftszettel fur Eva kuierte. Nos. I-36. 3 octobre 1939-5 juin 1940. 36 nos. French and German. 


\section{Establishment of Censorship}

One of the usual effects of war is the establishment of censorship for the printed, written, and spoken word on the one hand, and of an official propaganda service on the other, so as to keep public opinion in the desired channels. Provisions for this were made in the law of July I I, 1938, referred to above. There it was stipulated that "a general information service for the dissemination of all data useful in the interests of the nation" was to be set up even before a state of war existed. Thus the Commissariat Général à l'Information, established by decree of July 29, 1939, and further organized by the decrees of September I and I5, I939, came into existence. It consisted originally of five sections, four of which are of interest to librarians as publishing agencies: $2^{\mathrm{e}}$ Division, Service de la Documentation; $3^{\theta}$ Division, Service de l'Information à l'Intérieur et aux Colonies; $4^{e}$ Division, Service de l'Information à l'Etranger; $5^{\mathrm{e}}$ Division, Service de Presse et de la Censure.

\section{Information and Propaganda Services}

The economic information and propaganda services, which until then had been under the Présidence du Conseil, the service for the control of cinematographic films of the Ministry of Education, and the news and propaganda services of the national broadcasting organization, as well as the control of private broadcasting ordinarily under the Ministère des Postes, Télégraphe, et Téléphone, were all transferred to the new Commissariat. Finally, by decree of November 18, 1939, the Service d'Information et de Presse of the Ministère des Affaires Etrangères was placed under the authority of the Commissariat, to which the Service des
Oeuvres Françaises à l'Etranger, the cultural relations section of the Quai d'Orsay, had already been transferred. As a result, the Bulletin quotidien de Presse étrangère and the various press review bulletins for individual countries issued since 1916 by the Ministry of Foreign Affairs were being compiled from January 12, 1940, by the Commissariat Général à l'Information and from April I, I 940 , by the Ministère de l'Information. ${ }^{5}$ The last issued include:

Bulletin quotidien de Presse étrangère, 8 juin 1940, No. 7444.

Ironically, this last number contains nothing but a translation of Mr. Churchill's speech of June 4, 1940, in the House of Commons.

Bulletin périodique de la Presse allemande . . 23-25 mai 1940, No. 509.

Id. . . . Presse anglaise . . 9-I I mai 1940, No. 419

Id. . . Presse italienne $\mathrm{I}-2$ mai 1940, No. 349

Id. . . Presse japonaise $16-18$ mai 1940 , No. 82

Id. . . . Presse russe $18-20$ avril 1940, No. 294

Id. . . . Presse sudaméricaine . . I I-17 avril 1940, No. 224.

Id. . . Presse américaine 28-30 mars 1940, No. 359

Id. . . . Presse yougoslave 14-16 mars 1940, No. 134

Others were discontinued early in the war; thus, the Belgian (28-30 septembre I939, No. I33), the Roumanian (21-23 décembre 1939, No. I 50), the Swiss ( I6I 8 octobre 1939, No. 272), while the Polish bulletin stopped on the eve of war (24-26 août 1939, No. 272).

It is impossible at the present time to give anything but the most superficial

- In March 1940, following widespread criticism of the Commissariat and its head, Jean Giraudoux, the the Commissariat and its head, Jean Giraudoux, the as a ministry with Ludovic-Oscar Frossard as minister. 
account of the publications of the Commissariat and Ministry of Information up to the time of the downfall of France. Its printed and mimeographed material was held to be strictly confidential with the exception of the various press releases and propaganda publications. Within the department conditions similar to those in most French ministries prevailed, but in this instance they were aggravated by war psychology and fear of espionage. The result was a lack of coordination between the various divisions and bureaux of the department, each one producing bulletins, leaflets, pamphlets, or books of which the others knew little or nothing.

\section{Greatest Number}

The second and fourth divisions of the Commissariat Général à l'Information appear to be responsible for the greatest number of publications. Among these the following may be mentioned:

Revue sommaire de la Presse etrangère. No. I, 5 septembre 1939.

Sommaire, Presse parisienne. No. I, 2 septembre 1939.

From October 31, 1939, both were issued together as:

Revues de Presse. Nouvelles à Signaler. Daily, mimeographed.

This was for the internal use of government departments. In addition to outstanding news from the local and foreign press, it included news and articles suppressed by the censor and news picked up from neutral and enemy radio stations. From the outbreak of war, the public no longer had access to German, Italian, Russian, and many neutral papers. Sometimes, even entire issues of British periodicals were seized by the censor.
Other publications of a similar nature included :

Revue de la Presse régionale. janvier 1940-

Analyse de la Radio allemande. septembre I939-

In this same category from September Io, I939, on, were many unnumbered mimeographed bulletins and pamphlets containing the full text of Hitler's speeches, addresses by Goebbels, Hess, and other Nazi leaders, German high command communiqués (not published in the French press), German, Italian, and Russian propaganda broadcasts in French, extracts from the Swiss press, encyclicals and statements from the Vatican.

\section{Third Division Publications}

The $3 \mathrm{~d}$ Division issued the following publications which were considered at the time as highly confidential:

Compte-Rendu de Renseignements Concernant la Propagande italienne d'aprēs l'Étude de la Presse.

Compte-Rendu de Renseignements Concernant la Propagande allemande d'après l'Étude de la Presse.

Both were quarterly at first, then irregular, and were issued in printed form.

The Service de l'Information auprès des Formations Militaires et Ouvrières des Territoires d'Outre-Mer dans le Métropole, one of the bureaux of the $3 \mathrm{~d}$ Division, published a few numbers of a periodical intended for the French colored troops and labor battalions:

Bulletin des Armées d'Outre-Mer, Organe officiel du Centre de l'Entraide pour les Soldats et les Travailleurs des Territoires d'Outre-Mer dans le Métropole. Nos. I-4, décembre 1939-40, avril 
1940. Three editions: Edition arabe (Afrique du Nord); Edition afrique noire; Edition indochinoise.

In conjunction with the government's propaganda effort, various ministries published special information bulletins distributed through the Ministere de l'lnformation. Among these :

Bulletin d'Information agricole. No. I, 20 mars 1940. Fortnightly.

Ministère du Travail. Cabinet du Ministre. Bulletin de Renseignements. No. I, mars 1940.

Ministère de la Marine. Bulletin d'Information et de Presse. Fortnightly.

Ministère de l'Air. Bulletin hebdomadaire. Aéronautique française.

The $4^{\text {th }}$ Division was responsible for a flood of propaganda publications. It also commissioned or financed books and pamphlets with the imprints of well-known publishers such as Gallimard and Sorlot. Among these figure prominently speeches by Daladier, Reynaud, Giraudoux, and other members of the government, also the series Notre Combat with contributions from well-known writers and professors such as Edmond Vermeil. It also republished in a more convenient format the French Yellow Book, long a best seller at the moderate price of $7 \mathrm{fr} .50 .^{6}$

\section{End of Activities}

All these activities met a sudden and tragic end in the second week of June I940 when the government abandoned Paris.

The only two publications which have retained a quality of continuity through the upheavals of the last two years are the Journal officiel and the Bulletin municipal officiel de la Ville de Paris. The

\footnotetext{
- Ministere des Affaires etrangeres. Le Livre jaune français. Documents diplomatiques, 1938-39. Paris, Imprimerie nationale, 1939.
}

latter was interrupted but for one week during the days preceding the German occupation: No. 39 is dated 31 mai 6 juin 1940 and No. 40, 14 juin 1940. This, it will be remembered, was the day the Germans marched into Paris. The Bulletin municipal was the sole connecting link between the population and the municipal administration, all that was left of public authority. Frequently consisting of one leaf, often printed in fifty copies only due to lack of paper, containing brief but revealing regulations and appeals mostly concerning food supplies and relations with the occupying enemy, the collection of the Bulletin municipal of that period presents a poignant picture of conditions during the darkest hours of what was once the "city of light." It continues to appear regularly.

The Journal officiel was issued in Paris until June I I, I940, inclusive (No. I48) ; No. 149 dated $12 / 13$ juin 1940 consists of only one leaf and bears the imprint Tours (Indre-et-Loire) ; No. I 50 is dated $14 / 15 / 16 / 17$ juin 1940 and was published in $\mathrm{Pau}$ (Basses-Pyrénées). It contains the decree appointing Pétain chief of state in the place of Reynaud. From then until June 30 inclusive (No. I6I), the place of publication remained Pau. From No. I62, dated $1 / 2 / 3 / 4$ juillet 1940 , the imprint is Vichy (Allier). In the early days of August 1940 part of the technical staff of the Journal officiel returned to Paris and proceeded to reprint all the numbers issued in the provinces which were out of print. They were gradually supplied to subscribers in occupied France together with current issues. To date there are still two editions, one the original Vichy edition, the other the Paris reprint, usually available within twenty-four to forty-eight hours. 
The change in title which occurred on January 4, I94I, when the seventy year old Journal officiel de la Republique français became the Journal officiel de l'Etat francais marks the end of an era.

\section{Publication Resumed}

Beginning with August 3, 1940 (No. 910), the following resumed publication in occupied Paris:

Ministère du Commerce et de l'Industrie. Moniteur officiel du Commerce et de l'Industrie.

It reprints all important data, legislative and other, from the Journal officiel and the German Verordnungsblatt (VOBIF), with emphasis on economic and social matters. Catalogers may find helpful a feature appearing since February I3, I94I (No. 929): Guide administratif des Services ministériels français Actuellement à Paris.

Little has come from unoccupied France that is not of a propaganda character strongly reminiscent of Fascist and Nazi models. Much is made of the personality of Marshal Pétain. His portraits, news pictures of his inspection tours, his speeches in the form of booklets, posters, and handbills, biographies, and surveys of his achievements can be found everywhere. Few of these, if any, bear an indication of the department which is responsible for their publication: the Secrétariat Général de l'Information (previously the Haut Commissariat à la Propagande). ${ }^{7}$ This should not be confused with the Office Français d'Information created by decree of December 20, I940, an official news

\footnotetext{
${ }^{7}$ These are illustrative of this type of publication: Message du marechal Petain, Chef de l'Etat fran. cais. II octobre I940. [Grenoble, Impr. Allier]; Le marechal Petain. Appels aux Français. I 6 juin, 20 juin, 23 juin, 25 juin, I I juillet, I 3 aout, 6 septembre, 9 octobre, I I octobre, 30 octobre 1940. [Toulouse, Impr. Regionale.]
}

agency which took over the functions and property of the Havas news agency, January 27, 194I.

No effort is spared in Marshal Pétain's new France to popularize physical education and sports. To achieve this end the Commissariat Général à l'Education Générale et aux Sports issues a number of periodicals, leaflets, booklets, and posters, among which may be mentioned:

Education générale et sports. (Feuille d'Information.) No. I, janvier I94I. Vichy-Paris, Commissariat général [etc.] ; Lyn, Impr. Commerciale du Nouvelliste, 194I- No. 2 has subtitle: Feuille d'Information pour la Presse.

Bulletin d'Information. No. I, février I94I.

Les Cahiers de la France sportive. No. I, janvier I94I.

\section{In Technical Field}

In the technical field, publication of the Bulletin des Services techniques of the erstwhile Ministère de l'Air, now Secrétariat d'Etat à l'Aviation, appears to have been resumed. ${ }^{8}$ The Service Géographique de l'Armée was abolished July 12, 1940, and the Institut Géographique National subordinate to the Ministere des Travaux Publics was created to take its place. Its functions are described in the decree of April 8, I94I, published in the Journal officiel of April 28. The following is from its Algerian section:

Etat Français. Service Cartographique de l'Algérie. Carte forestière de l'Algérie et de la Tunisie, pub. par ordre de M. l'amiral Abrial, gouverneur général de I'Algérie. Notice par P. de Peyerimhoff. ... Alger, 1941.

\footnotetext{
${ }^{8}$ Publications scientifiques et techniques du Secretariat, d'Etat a l'Aviation. Bulletin des Services techniques. No. 92, fevrier r94I. Id. No. 93 janvier I94I. Paris, Gauthier-Villars, I94I.
} 
There is one Vichy publication of firstrate importance which together with the Journal officiel gives a clear picture of all government activity. This is an unassuming looking bulletin entitled Informations générales. ${ }^{9}$ It is designed to keep the diplomatic missions abroad informed on "the situation of the country and the reforms being accomplished," and has been published weekly since September 8, I940, (the first number covered August I I-3 I) with the number of pages from seven to sixty per issue. The subject matter is divided into sixteen sections entitled as follows: Aspect Général de la Vie française; Relations avec l'extérieur; Politique et Administration; Justice; La Vie sociale et profesionnelle; Famille et Santé; Armée, Marine, Aviation militaire et Prisonniers de Guerre; Travail et Production; Agriculture et Ravitaillement; Commerce et Finances; Transports et Travaux publics; La Vie de l'Empire; Instruction publique et Jeunesse; Les Beaux-Arts et les Lettres; Presse et Radiodiffusion; Revue de Presse. The section Beaux-Arts et Lettres includes mention of new books and periodicals.

\footnotetext{
9 Ministère de l'Interieur. Bureau d'Etudes juridiques et de Documentation generale. Informations generales. No. I- 8 septembre 1940- . [Vichy,
[Vich Wallon] 1940- . 38 nos, up to May 20, 1941 .
}

This publication was preceded by an official pamphlet covering the period from July Io, the date of the new constitutional law, to August Io, and is entitled: $U_{n}$ Mois de Rénovation nationale.

According to a notice in No. I of the Informations générales, it was planned to issue a Bulletin de la Radio nationale, but no copy of this has come to hand.

\section{Official Gazette of the Free French}

Finally, it may be of interest to mention the official gazette of the Free French under General de Gaulle: Journal officiel de la France Libre. $\mathrm{I}^{\mathrm{re}}$ année, No. I, 20 janvier I94I. London, 4 Carlton Gardens, S.W.I. This looks very much like the Vichy official gazette and includes the following documents: organic texts; "ordinance-laws;" decrees; certain military orders; regulations; circulars and public notices; various administrative documents.

Similarly, French Equatorial Africa, which has joined General de Gaulle, has its official gazette: Journal officiel de l'Afrique française Libre et de l'Afrique Equatoriale Française. Brazzaville, août I940- . No. I8, dated September I, I940, contains Organic Act No. I constituting the government of Free French Africa. 